\title{
Earthworm: A Potential and Sustainable Source for Soil Fertility - An Altitude Based Biophysical Study
}

\author{
M. Kanchilakshmi, Arockiam Thaddeus \\ Research Centre of Zoology, Jayaraj Annapackiam College for Women (Autonomous), Periyakulam, Tamil Nadu, South India
}

Email address:

kanchilakshmik@yahoo.com (M. Kanchilakshmi), arockiamt@yahoo.co.in (A. Thaddeus)

\section{To cite this article:}

M. Kanchilakshmi, Arockiam Thaddeus. Earthworm: A potential and Sustainable Source for Soil Fertility - An Altitude Based Biophysical Study. International Journal of Environmental Protection and Policy. Vol. 4, No. 3, 2016, pp. 77-85. doi: 10.11648/j.ijepp.20160403.15

Received: March 31, 2016; Accepted: May 21, 2016; Published: May 23, 2016

\begin{abstract}
An altitude based study was undertaken in the present investigation to find out the status of ecological indices of earthworms in turn to assess the fertility of the soil. Evidences are ample to prove that the physico chemical factors of the environment /soil are responsible for greater ecological indices of earthworms. In the present investigation also it was proved that the earthworm abundance is responsible for the soil fertility for which supportive studies were made on 1. the population dynamics of earthworms, 2. Size of body pores on the skin of earthworms and the secretion of coelomic fluid and the 3. Physico chemical factors of the soil in the area surveyed. It was also found that the earthworm abundance was found to be greater in Meghamalai hills of Theni district compared to that of Sirumalai hills of Dindigul district but when the plains and hills of both the district were compared the earthworm population was found to be more in the plains. Atomic force microscopic studies were also made to measure the size of the body pores of the skin of earthworms of plains and hills. It was found that the number of body pores is more and their size is also larger in the earthworms of plain lands. As a result ceolomic fluid secretion was more. The coelomic fluid contains more than forty proteins and exhibits several biological activities and it supplements the soil with nutrients. Moreover, physical parameters of the soil samples of hills and plains such as rainfall and temperature and chemical parameters such as Ec, $\mathrm{p}^{\mathrm{H}}$, Nitrogen, Phosphorous, Potassium, Calcium, Magnesium, Iron, Zinc, Copper, Boron, were found to be conducive for the growth and multiplication of earthworms in the soil of the plain lands than the hills. Hence, it can be concluded that the earthworm population has got its influence on soil fertility; the more the number of earthworms, more availability of coelomic fluid, which indirectly influences the fertility of the soil, enhances the economy of the nation and the world at large. In total the global worming suppresses global warming.
\end{abstract}

Keywords: Earthworm Abundance, Hills, Plain Lands, Physico Chemical Factors, Coelomic Fluid, Soil Fertility

\section{Introduction}

Earthworm density and biomass are fluctuated seasonally with both physical and organic factors of soil. Earthworms are an important integral of the invertebrate community in most soils, both in terms of their contribution to overall below ground biomass on soil biogeochemical cycles [1, 2, and 3]. The distribution of earthworms in soil depends on components like soil moisture, availability of organic matter and $\mathrm{pH}$ of the soil. They appear in disparate terrain mainly those which are unilluminated and moist. Earthworms are generally absent or rare in soil with a very coarse texture, in soil with high clay content, or soil with $\mathrm{pH}<4$ [4]. Earthworm density and biomass alternated periodically with both physical and organic factor of soil have been known to influence the abundance and distribution of earthworms [5]. The coelomic fluid cells have been analyzed and were contrasted with the population abundance of the worms. The earthworm coelomic fluid cells (coelomocytes) have been analyzed by measuring its cell size micrometrically. Earthworms are obvious target organisms for environmental studies. In recent years, earthworms have been used extensively in ecotoxicology to evaluate the consequent of spread contaminants present in soils [6]. In this aspect, coelomocytes and immunological end points such as phagocytosis have been demonstrated as sensitive biomarkers for trace metal monitoring [7]. To this termination, numerous techniques have been evolved to procure the coelomocytes from the earthworms. The protein component of earthworm 
cuticle is related with an immensely much huge amount of polysaccharide material than is found in the vertebrate collagens. Earthworm's cuticle also belongs to a growing number of collagens [8].

The work on the population density (number $/ \mathrm{m}^{2}$ ) of earthworms based on the distribution in different localities and different ecosystem and their role in soil fertility tested on plant growth was plenty in the past; but work on coelomic fluid and their role in the replenishment of nutrients to the soil and their sustainability are meager. Moreover, the study on earthworm population and the nature of body pores on the skin of the earthworm based on altitude is scarce. Hence, the present study aims at comparing the population dynamics of earthworm at two different altitudes (plains and hills). Supportive studies were made such as population density in different altitudes, physico chemical nature of the soil of the area of study, size of the body pores and skin of the earthworms, and nature of the body pores based on the altitude by comparing a plain land, and a hill of 1500 meters height from the sea level. The earthworm population of two hill stations of two districts (Meghamalai hills of Theni district and Sirumalai hills of Dindigul district) was also surveyed and compared. Meghamalai hill latitude $-9^{\circ} 39^{\prime}$ 'and $10^{\circ} 30^{\prime} \mathrm{N}$ and $78^{\circ} 30^{\prime} \mathrm{E}$, Sirumalai hill latitude $10^{\circ} 05^{\prime}$ and $10^{\circ} 09^{\prime} \mathrm{N}$ longitude $77^{\circ} 30^{\prime}$ and $78^{\circ} 20 \mathrm{E}$.

\section{Materials and Methods}

\subsection{Study Area}

An extensive survey of earthworm was carried out in area located in the nearby Sirumalai hill station at Dindigul Taluk of Dindigul District and Meghamalai hill station at Aundipatti Taluk of Theni District. The earthworm survey was carried out during September 2013 to Aug 2014.

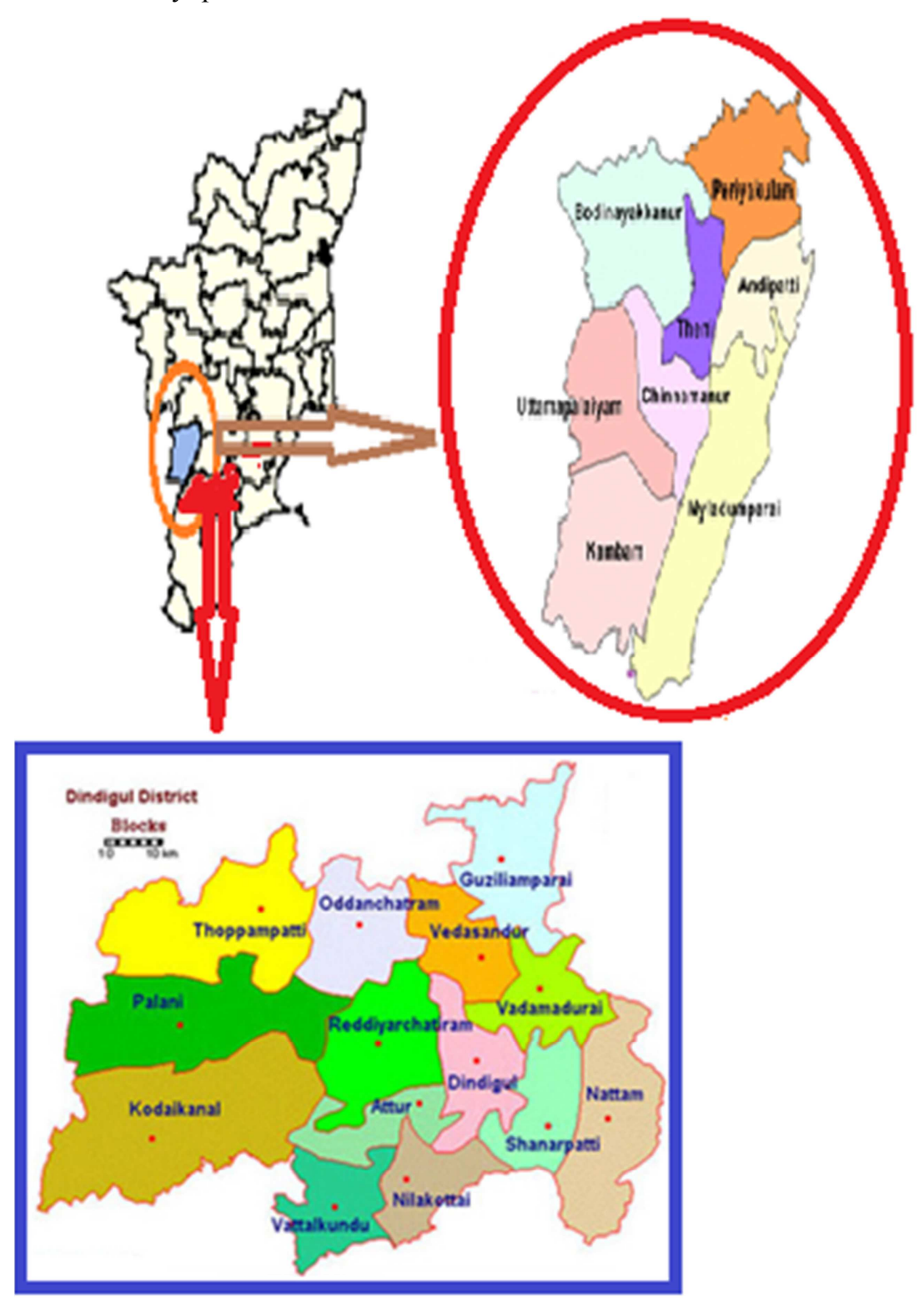

Figure 1. Map showing the study area. 


\subsection{Field Sampling}

Four different sampling sites were chosen for the survey of earthworms. The sampling sites include two different ecosystems namely coffee plantation in Sirumalai hills, grapes plantation in Kamalapuram (Dindigul District) and Tea plantation in Meghamalai hills, grapes plantation in Odaipatti (Theni District). The sites are surrounded by stone hills and experience a distinct dry season from March to July. The average annual temperature was $21^{\circ} \mathrm{C}-30^{\circ} \mathrm{C}$.

\subsection{Meghamalai}

Generally called High Wavy Mountains, is a cool and misty mountain range situated in the Western Ghats in Theni district, Tamil Nadu, in South India. The place is situated at an elevation of 1,500 $\mathrm{m}$ above sea level and it is rich in flora and fauna. Mass of the rainfall is received during the North East monsoon in the months of October, November and December.

\subsection{Sirumalai}

It is a region situated $25 \mathrm{~km}(16 \mathrm{mi})$ from Dindigul is located at $10.35^{\circ} \mathrm{N} 77.95^{\circ} \mathrm{E}$ longitude and $40 \mathrm{~km}(25 \mathrm{mi})$ from Madurai, Tamil Nadu, India., There are many high hills in the area. Sirumalai is a dense forest region with a moderate climate throughout the year. The altitude of the hill is 1600 meters above sea level, and it contains diversified flora and fauna and a variety of animals. The survey and collection was done for one year starting from September 2013 to August 2014. The annual temperature is $22-32^{\circ} \mathrm{C}$. Dindigul receives rainfall with an average of $812 \mathrm{~mm}(32.0 \mathrm{in})$ annually. The South west monsoon, with an onset in June and lasting up to August, brings scanty rainfall.

\subsection{Collection of Earthworms}

Earthworms were collected from different habitats by digging the soil and hand sorting method. The grasses and leaf litter were cleared from the surface of the sampling site per sampling occasion was marked. The soil was dug and organic matter was analyzed deliberately and was transported to the laboratory along with their native soil in wet cloth bags. The number of each earthworm species indicated per square meter was classified as abundant. The ecological categories of earthworm species were also recorded. The physicochemical properties of soil from each sampling site were also analyzed to establish the possible species habitat relationship.

\subsection{Preservation}

Collected worms were sacrificed using $70 \%$ ethyl alcohol Earthworms were identified to the species level with the help of monographs of many researchers. $[9,10,11]$

\subsection{Harvesting of Coelomicfluid}

\section{Cold shock method}

Earthworms were collected from different habitats by digging the soil and hand sorting method. The grasses and leaf litter were cleared from the surface of the sampling site per sampling occasion was marked. In the present study earthworms (Eudrilus euginea) were subjected to cold shock method for the collection of coelomic fluid. Earthworms were using of cold-shock method of ice packing and the fluid was collected in a clean dry test tube. The earthworm coelomocytes were analyzed with the help of Trinocular Microscope to observe the cells and are identified and photographed.

\subsection{AFM Study}

This AFM work was conducted in the Department of physics, UGC-DAE consortium, Devi Ahilya Vishwa Vidyalaya University, Indore, Madhya pradesh. North India. The skin pieces of earthworms of the size of approximately $0.5 \mathrm{~cm} \times 0.5 \mathrm{~cm}$ were cut from dorsal skin and fixed over a magnetic holder by using double side adhesive tape. Nano scope E of AFM from Digital instruments, USA for imaging in contact mode, Triangular cantilevers of Si3N4, 100 micron, wide leg, with a force constant of $0.58 \mathrm{~N} / \mathrm{M}$ was used in the present investigation. Scan made on areas of 5 micron $\times 1$ micron were selected on the earthworm skin surface for analysis. The body pores and roughness parameters of the sample (Earthworm skin) were determined by AFM.

\subsection{Calculation of Ecological Indices}

During random survey some habitats were selected and ecological indices were calculated. Diversity index $\left(\mathrm{H}^{\prime}=\sum\right.$ pi $\ln$ pi) where $\mathrm{pi}=$ relative abundance of the species which is estimated by $\mathrm{pi}=\mathrm{n}_{1} / \mathrm{N}$, species dominance $\left(\mathrm{C}=\sum(\mathrm{pi})^{2}\right)$, species richness $(\mathrm{d}=\mathrm{S}-1 / \mathrm{ln} \mathrm{N}$ where $\mathrm{S}$ is the total number of species) and evenness $\left(\mathrm{e}=\mathrm{H}^{\prime} / \mathrm{ln} \mathrm{S}\right)$ were calculated for some selected ecosystem during random survey by standard methods $[12,13]$.

\subsection{Soil Analysis}

Soil samples were taken from each site for analysis. Temperature at $10 \mathrm{~cm}$ depth was measured by soil thermometer and $\mathrm{pH}$, Electrical conductivity, carbon, Total nitrogen, and potassium, phosphorous were analyzed.

\section{Result and Discussion}

The occurrence and density of earthworms, analysis of soil sample, temperature, moisture, EC, organic carbon, organic matter, total nitrogen, phosphate, potassium and magnesium are presented in along with rain fall, temperature and humidity (Table 1). The maximum rainfall $(\mathrm{mm})$ and Humidity (\%) was recorded in theni district compared with dindigul district (Figure 2). The maximum earthworm abundance in meghamalai hills, and plain lands of Theni district. showing species composition of earthworms in various altitude and ecosystem. From Shannon abundance, diversity index and evenness index, it is apparent that the number of species of earthworm was high in meghamalai hill 
and lower in Sirumalai hills (figure 3, 4 and figure 5). The results of the present study also revealed that the evenness was recorded as high in meghamalai hills and was lower in Sirumalai hills (figure 6 and figure 7). Earthworms are very sensitive to soil $\mathrm{p}^{\mathrm{H}}$ [14]. Acidic soils are characterized by higher opportunity of metal ions [15] that cause unfriendly conditions for earthworms. In the present study the clay soil with an electrical conductivity of $0.20, p^{\mathrm{H}} 6.5-7.50$ along with high moisture holding capacity appears to be favouarable for high earthworm abundance and diversity. This may be associated with the ability of clay soil to retain more moisture for a prolonged time due to its fine particles. The finding is in accordance with [16] various studies which have indicated a decrease in earthworm population in response to dry seasons [3, 17, 18]. However, in Sirumalai, low species diversity index was attributed to the peaty soil with dry soil which has low water holding capacity. Moisture is one of the key factors affecting the survival of all earthworm species [3, 19] Earthworm diversity was low in the plain land; only two to three earthworm species were found. The finding was in consonance with authors [20] who reported that urban and agricultural lands are generally characterized with low earthworm diversity. Human activities may disrupt and limit the development of the earthworm community in agricultural land. A significant decline in number of individual earthworms in summer can be attributed to changes in soil temperature and moisture [21]. The result of present study revealed that the diversity of earthworm species in plain lands of two districts was found to be high in Theni and Dindigul districts during NorthWest monsoon and lower in summer (figure 8 and figure 9). Similar results were shown by [22] who reported higher diversity indices and evenness in cultivated soil whereas [19] reported the same from vegetable soil. The results revealed that the evenness value was recorded high during northwest monsoon and lower in summer (figure 10 and figure 11).

Table 1. Physico-chemical parameters of soil samples of Meghamalai hills (Theni district) and Sirumalai hills (Dindigul). Period of survey: September 2013 to Aug 2014.

\begin{tabular}{lllll}
\hline \multirow{2}{*}{ Parameters Habitats } & Sirumalai (Hill) & Meghamalai (Hill) & Dindigul (Plain) & Theni (Plain) \\
\cline { 2 - 5 } & Coffee & Tea & Vineyard & Vineyard \\
\hline Type of soil & Coastral with peaty soil & Clay soil & Clay soil & Red \\
Colour & Black & Brown & Brown & 0.28 \\
Ec & 0.28 & 0.20 & 0.40 & 6.9 \\
pH & 6.69 & 7.50 & 7.8 & $29-30$ \\
Temperature & $17^{\circ}-21^{\circ} \mathrm{C}$ & $15-17^{\circ} \mathrm{C}$ & $30-32$ & 65 \\
Nitrogen & 7.3 & 8.3 & 74 & 23 \\
Potassium & 3.3 & 4.3 & 4 & 182 \\
Phosphorous & 1.95 & 3.0 & 50 & 4.7 \\
Iron & 11.8 & 12.1 & 5.2 & 2.2 \\
Manganese & 9.2 & 11.3 & 2.7 & 0.81 \\
Zinc & 1.62 & - & 0.81 & 0.71 \\
Copper & 3.5 & 2.56 & 0.79 & 0 \\
Boron & 0 & 0 & 0 & \\
\hline
\end{tabular}

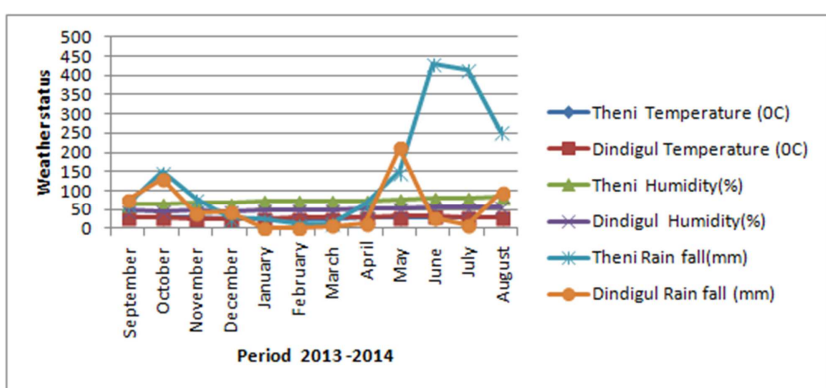

Figure 2. Weather Condition in Theni and Dindigul District.

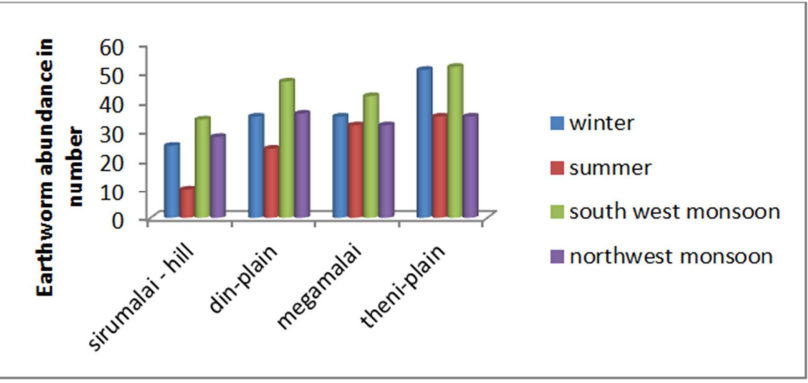

Figure 3. Abundance of earthworm population in hills and plains (Theni and Dindigul Districts). 


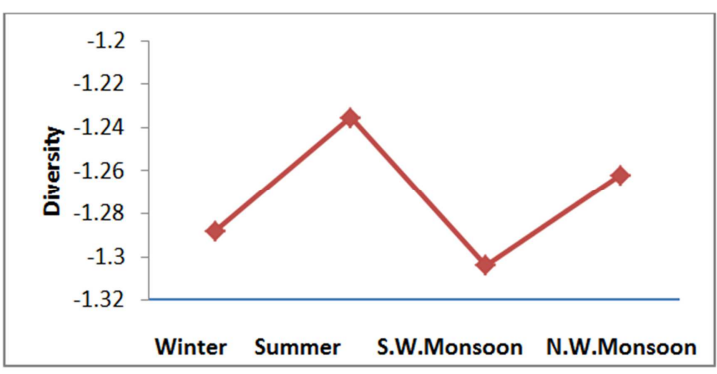

Figure 4. Diversity of earthworm species in Meghamalai hills (Theni district).

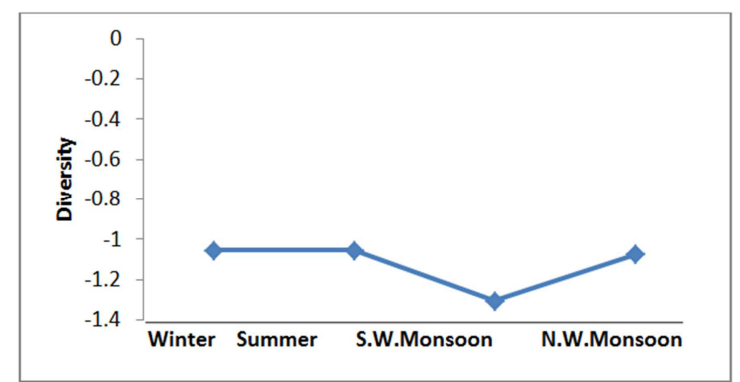

Figure 5. Diversity of earthworm species in the Sirumalai hill of Dindigul district.

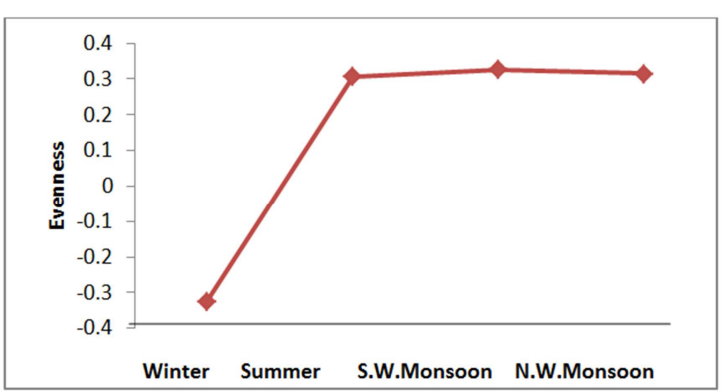

Figure 6. Evenness of earthworm species of Meghamalai in Theni District.

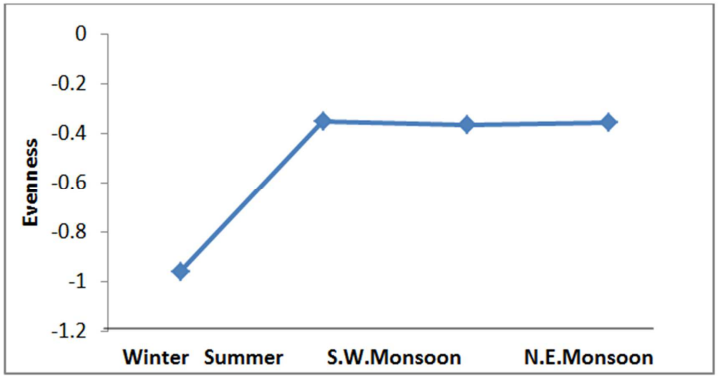

Figure 7. Evenness of earthworm species from sirumalai in dindigul district.

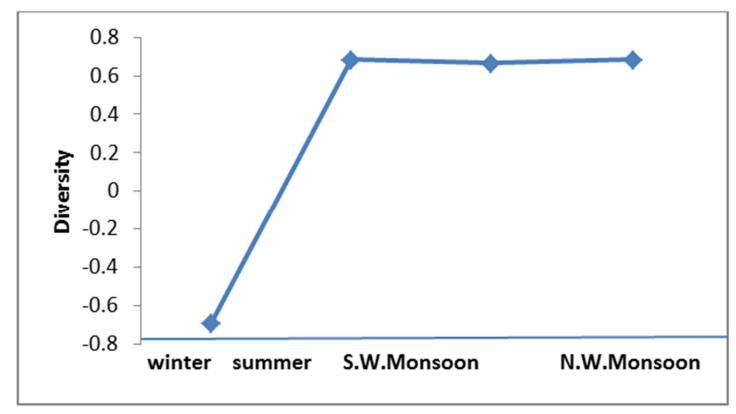

Figure 8. Diversity of earthworm species of plain in Theni District.

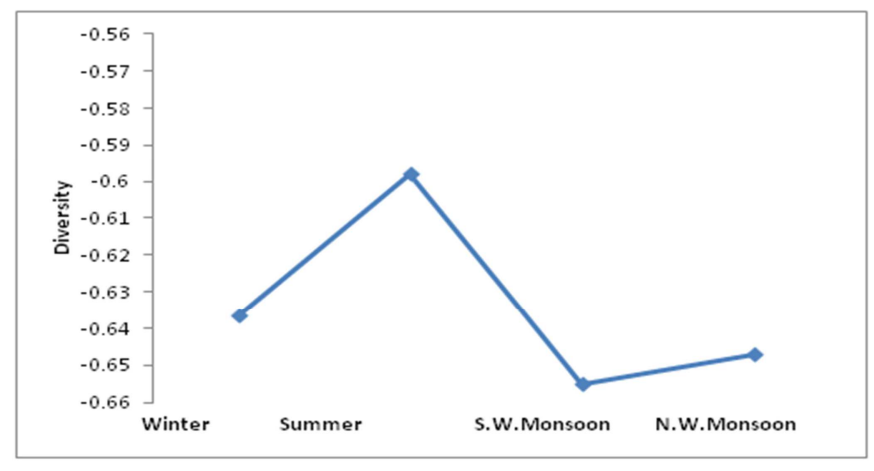

Figure 9. Diversity of earthworm species from plain in dindigul district.

Ample of evidences have been reported that the abundance of earthworm population in terms of ecological indices of earthworms are mainly due to ecological factors. But in the present investigation earthworm abundance or the ecological indices of the earthworms are responsible for the soil fertility. It was supported by the recent workers that [23, 24] soil structure, gas dynamics, water flow, and $\mathrm{C} \& \mathrm{~N}$ departure and stabilization may be altered by the presence and community structure of earthworms. Earthworms are very sensitive to touch, light and dryness. Water-logging in the soil can origin them to come to the surface. Worms can tolerate a temperature range between $5^{\circ} \mathrm{C}$ to $29^{\circ} \mathrm{C}$. A temperature of $20^{\circ} \mathrm{C}$ to $25^{\circ} \mathrm{C}$ and moisture of $50-60$ percent is optimum for earthworm function [25]. Earthworm diversity is influenced largely by soil nutrients and rainfall patterns [26]. It was also supported by the contributors [1] that earthworm ecological groups have variable effects on the soil physical, chemical and biological properties.

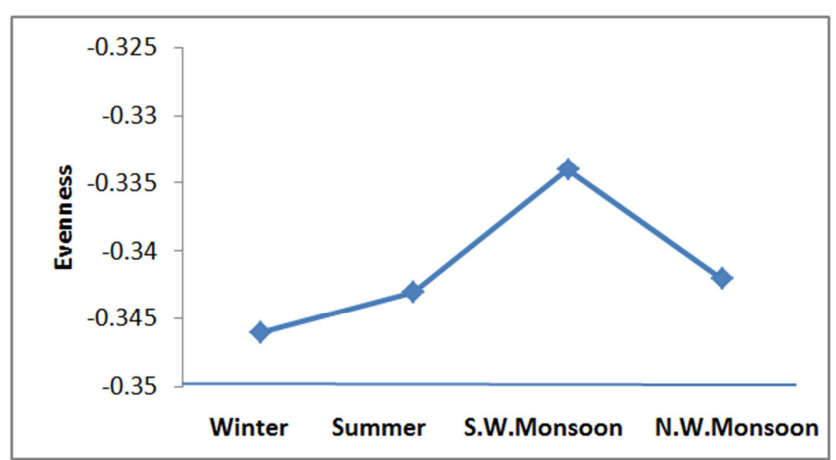

Figure 10. Evenness of earthworm species in plain (Theni District).

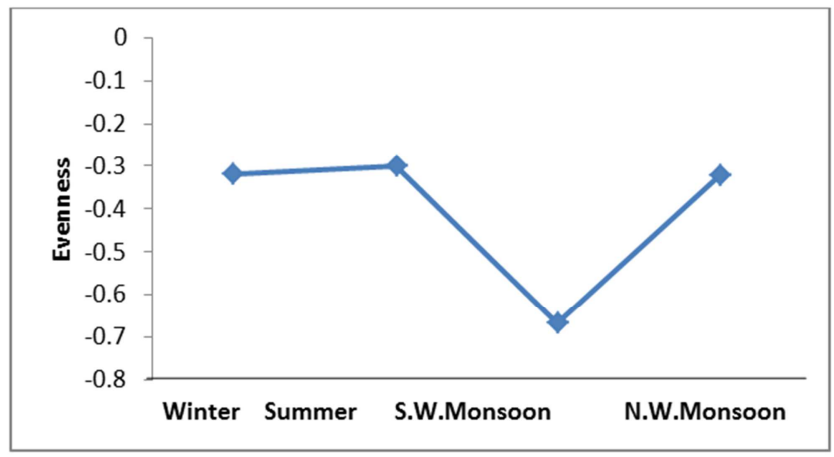

Figure 11. Evenness of earthworm species in plains (Dindigul District). 
In the present investigation, Coelomocytes from the body fluid of the earthworm Eudrillus euginea were studied using Trinocular microscopy and were photographed. Cells were coinciding with the immune cells. Different size of cells of amobeocytes were found to be $6 \mu \mathrm{m}$ and $10 \mu \mathrm{m}$ and granulocytes of $5 \mu \mathrm{m}$ and $8 \mu \mathrm{m}$ respectively in the earthworms collected from hills and plain lands of Dindigul and Theni District Figure 12. AFM studies were also made on the earthworm skin and the size of the body pores were measured. The pore size was found to be $1.000 \mu \mathrm{m}, 1.500 \mu$ $\mathrm{m}$ and $5.66 \mu \mathrm{m}$ in the earthworms collected from hills and plain lands of Dindigul and Theni District Figure 13. This is in concordance with the authors [27] who reported that all these coelomic cells are involved in various aspects of cellular and humoral immunity, the former by phagocytosis. Chlorocytes/ eleocytes resemble the invertebrate live cells in certain function. For example, they are involved in the metabolism and storage of glycogen and lipids. They also transport nutrient via the circulation into the coelomic fluids as well as various cells and organ [28]. Cold shock method of fluid collection was found to be the safest method of coelomic fluid. Cold shock method produced $1.5 \mathrm{ml}$ of fluid collection in 30 minutes. [29, 30]. The phenomenon has been exploited as noninvasive methods of sampling coelomic

Theni

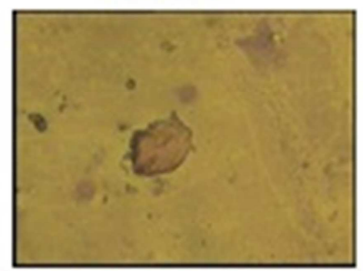

(a) A moebocytes cell size $6 \mu \mathrm{m}$

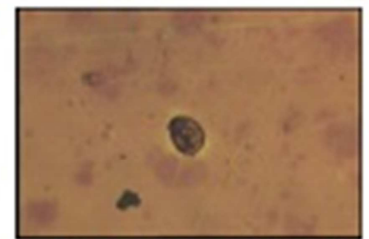

(c) Granulocytes cell size $5 \mu \mathrm{m}$

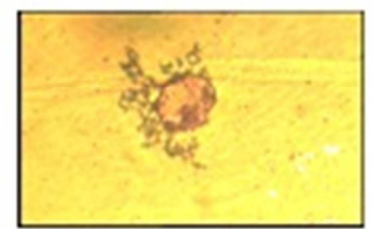

(e) Amoebocytes cell size $10 \mu \mathrm{m}$

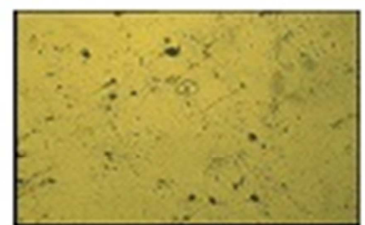

(g) Amoebocytes cell size $6 \mu \mathrm{m}$ fluids and coelomocytes using electric current [31].

The coelomic fluid cells have been analyzed and were compared with the body pores and globular proteins in the skin of the earthworms. Coelomocytes are considered as the immune cells of coelomate animals (Annelids, Mollusca, Arthopoda). These cells are of the types of leukocytes that have long been considered to constitute the major innate immune defense system of these animals. It has been found that coelomic fluid of the earthworms contains more than 40 proteins and exhibits several biological accomplishments as follows: cytolytic, proteolytic, antimicrobial, hemolytic, heam agglutinating, tumorolytic, mitogenic activities $[32,33$, 34 , and 35]. It was also reported [36] that the coelomic fluid gains the production of Rhidium by $20-25 \%$ due to an increase in soil organic matter. furthermore, the inclusion of coelomic fluid to soil used in growth of 1) Seasamum indicum, Vinga radiate, Vinga mungo increased plant growth rates $[37,38] 2)$ rice, bean, corn, tobacco, oats and peanuts lead to increase their manufacture and length of roots[39, 40]. This is in support to the present investigation that the more the number of earthworms the more will be the excretion of coelomic fluid which in turn improves soil fertility which was assessed by physico-chemical analysis of the soil.

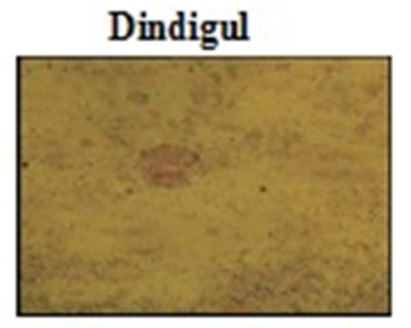

(b) Granulocytes cell size $5 \mu \mathrm{m}$

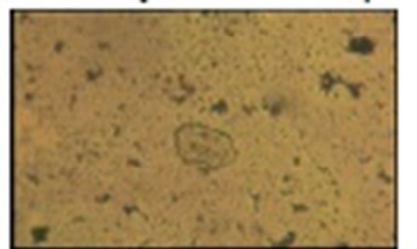

(d) Granulocytes cell size $5 \mu \mathrm{m}$

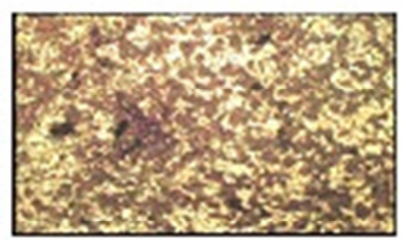

(f) Granulocytes cell size $8 \mu \mathrm{m}$

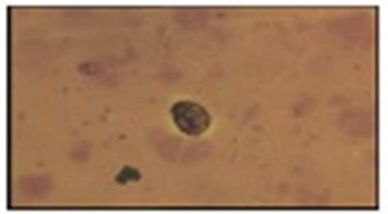

(h) Granulocytes cell size $8 \mu \mathrm{m}$

Figure 12. Types of coelomocytes in coelomic fluid of earthworms. 
Dindigul (Sirumalai hills)

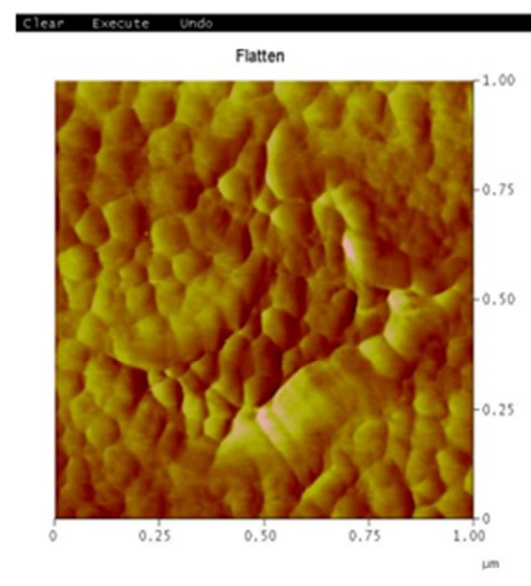

eet. 003
Theni (Meghamalai hills)
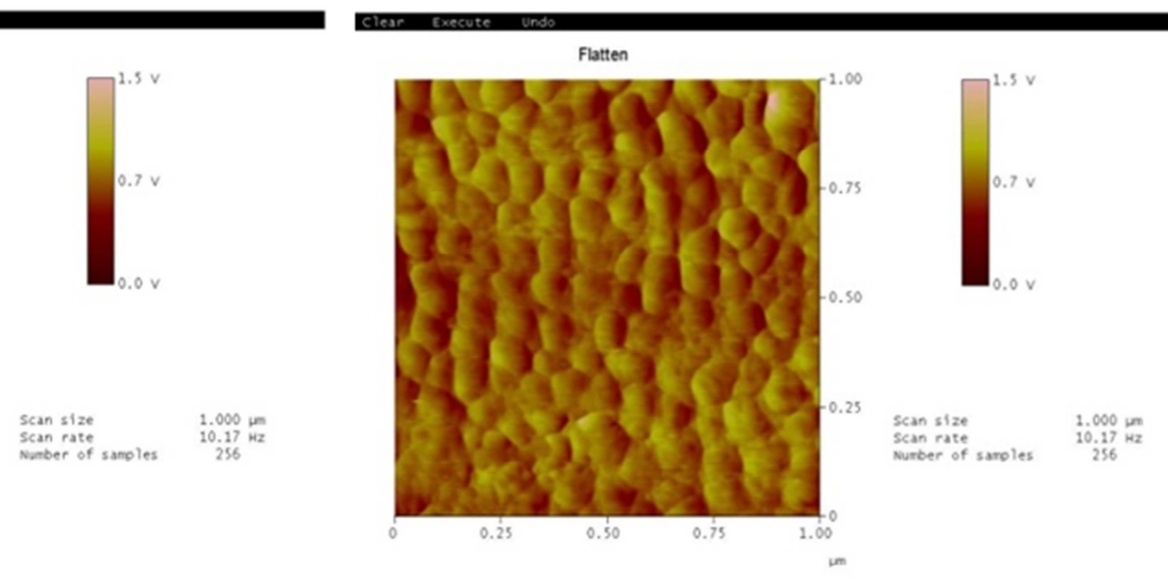

exts.005 (a)

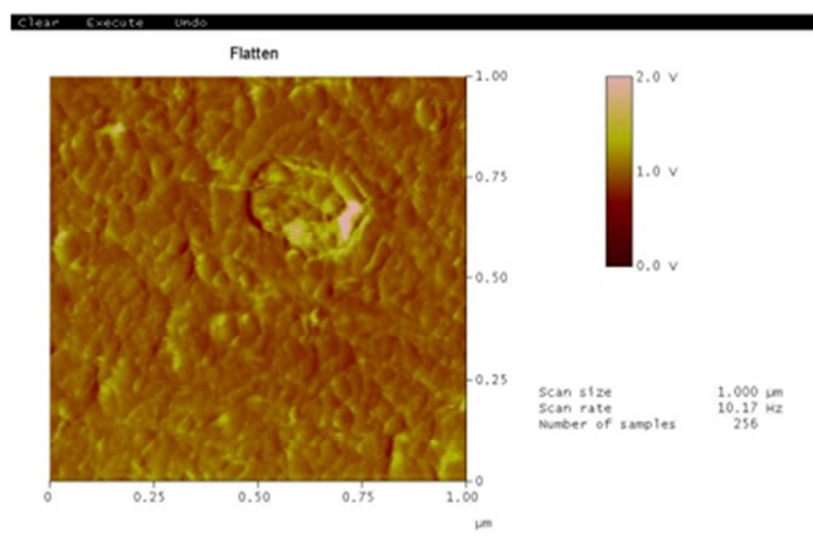

eas. 001

(c)

Plain lands

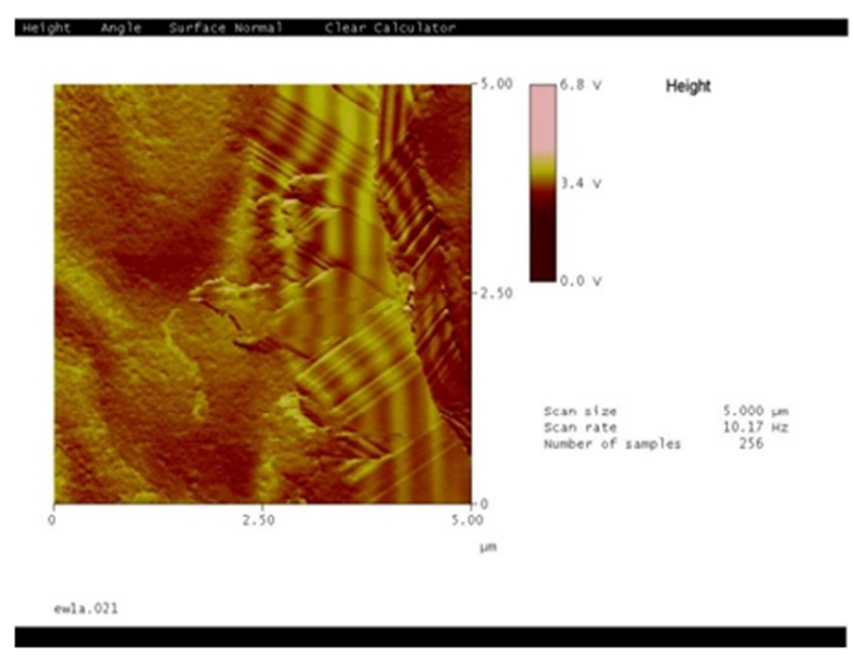

(e) (b)

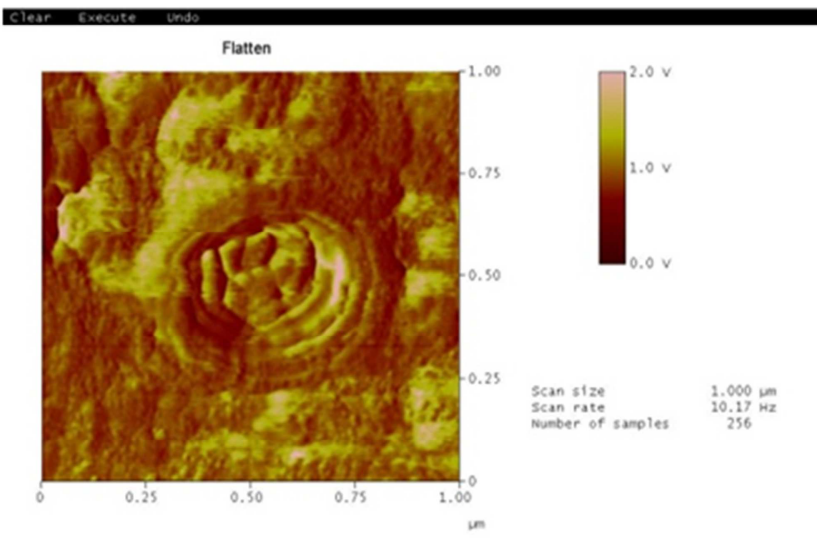

ent.003

(d)

Plain lands

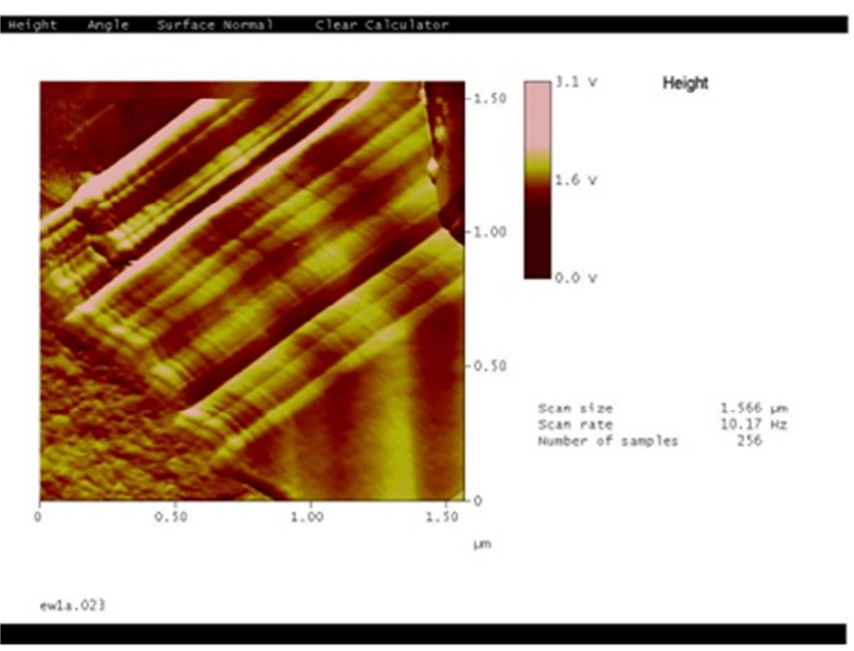

(f)

Figure 13. AFM studies on body pores of earthworms of two districts (Plain lands \& hills). 
The high accessibility of feed and moisture content kept in this man made environment appear to be the positive constituents. [41] Fragoso et al., (1999) reported that the structural composition of earthworm communities varies depending on the type of agro ecosystem.

\section{Conclusion}

The altitude plays a major role in the population density of earthworms along with the climatic factors. It doesn't mean that the population density increases not only with the increase in altitude but also the physico chemical factors of the soil in the ecosystem plays their role. At the same time, it was proved in the present investigation that there is sustainability in the soil fertility in the region where there is earthworm abundance, and was supported by the biophysical studies on coelomiic fluid and the body pores of earthworms with the help of Trinocular microscopy and Atomic Force Microscopy. In nutshell greater the earthworm abundance in a particular area, greater will be the soil fertility of that area. Which indirectly enhances the economy of the nation and the world at large. In total the global worming suppresses global warming.

\section{Acknowledgement}

I thank my institution and my guide for providing all facilities to carry out this work. Thanks are due to University Grants Commission, New Delhi for funding and UGC - DAE Consortium, Indore, Madhya Pradesh for the lab facilities to do AFM studies.

\section{References}

[1] K. E. Lee, "Earthworms: Their Ecology and Relationships with Soil and Land Use”. 1985. Vol. 5. Academic Press, New York.

[2] S. W. James, "Soil nitrogen, phosphorus and organic matter processing by earthworms in tall grass prairie". Ecology, 1991, 72, pp. 2102-2109.

[3] P. J. Bohlen, W. M. Edwards and C. A. Edwards. "Earthworm community structure and diversity in experimental agricultural watersheds in Northeastern Ohio". 1995, Plant and Soil 170, pp. 233-239.

[4] K. Gunathilagraj P. T. Ramesh, "Degradation of coir wastes and tapoica peels by earthworms". In Training Program in Vermiculture. New Delhi: Indian Council of Agricultural Research 1996 (ICAR).

[5] W. White, "An earthworm is born, starting". Publishing company, New York. 1975.

[6] M. A. Giggleman, L. C. Fitzpatrick, A. J. Goven, B. J. Venables, Effects of pentachlorophenol on survival of earthworm (Lumbricus terrestris) and phagocytosis by their immuno active coelomocytes. Environ. Toxicol. Chem. 1998. $17,2341-2394$
[7] S. Senthil Kumar, M. V. Sriram Chandrasekaran and K. Haripriya., "Effect of vermicompost and fertilizer on the growth and yield of rose". J. Interacademicia, 2004. 8, pp. 207-210.

[8] P. Ville, P. Roch, E. L. Cooper, P. Masson, J. Narbonne, "PCBs increase molecular-related activities (lysozyme, antibacterial, hemolysis, proteases) but inhibit macrophagerelated functions (phagocytosis, wound healing) in the earthworms". J. Invert. Pathol. 1995. 65, pp. 217-224.

[9] G. E. Gates, Burmese earthworm, "An introduction to the systematic and biology of magadrile oligochaetas with reference to southeast Asia", Transaction of the American philoshophical society, 1972 62, pp. 1-326.

[10] J. M. Julka, "The fauna of India and the adjacent countries. Megascoleccidae: octochaetidae; (Earthworm) Haplotaxida, Lumbricina": XIV, Zoological survey of india, culcutta., 1988. 400 .

[11] J. Stephenson, Oligochaeta, the fauna of British India including Ceylon and Burma, Taylor and Francis Ltd. London, 1923XXIV +518pp.

[12] C. E. Shannon and W. Weaver "The mathematical theory of communication", university Illinois press, Urbana, 1949. pp. 117.

[13] E. H. Simpson, Measurement of diversity, Nature, London 1949. pp. 163-681.

[14] C. A. Edwards, Report on the second stage in the development of a standardized laboratory method for assessing the toxicity of chemical substances to earthworms. Commission of the European Communities, Brussels, Luxemburg, 1984.

[15] N. C. Brady, "The nature and property of soil". Collier McMillan Press, London1984.

[16] G. H. Baker, P. J. Cartera, J. P. Curry, O. Cultreric \& A. Beck. "Clay content of soil and its influence on the abundance of Aporrectodea trapezoides Duges (Lumbricidae)". Applied Soil Ecology 1989, pp. 333-337.

[17] G. X. Gonzalez, Zou \& S. Borges. "Earthworm abundance and species composition in abandoned 298 earthworm diversity and population density in kaki bukit tropical croplands: comparisons of tree plantation and secondary forests". Pedobiologia 1996, 40, pp. 385-391.

[18] I. S. Najar, and A. B. Khan. "Earthworm communities of Kashmir Valley, India”. Tropical Ecology, 2011. 52, pp. 151162.

[19] C. A. Edwards, and P. J. Bohlen. "Biology and ecology of earthworms". 3rd ed. Chapman \& Hall, London, UK, 1996.

[20] K. M. Smetak, J. L. Johnson-Maynard \& J. E. Lloyd. "Earthworm population density and diversity in different aged urban systems". Applied Soil Ecology 2007, 37, pp. 161-168.

[21] J. K. Whalen, R. W. Parmelee \& C. A. Edwards. "Population dynamics of earthworm communities in corn agroecosystems receiving organic or inorganic fertilizer amendments". Biology and Fertility of Soils 1998. 27, pp. 400-407.

[22] G. Tripathi, P. Bhardwaj. "Comparative studies on biomass production, life cycles and composting efficiency of Eisenia fetida (Savigny) and Lampito mauritii (Kinberg)", Biores. Technol., 2004. 92, pp. 275-283. 
[23] A. J. Vanden Bygaart, C. A. Fox, D. Follow, and R. Protz. "Estimating earthworm influenced -soil structure by morphometric image analysis". Soil Science Society of America Journal 2000 64, pp. 982-988.

[24] R. V. Pouyat, M. M. Carreiro. "Contrasting controls on decomposition of oak leaf litter along an urban-rural land use gradient. Oecologia”. 2003, pp135: 288-298.

[25] P. Hand. "Earthworm biotechnology. In: Greenshields R(Ed) resources and application of biotechnology": The New Wave Macmillan Press, Newyark, US, 1988, pp 214-257.

[26] C. Fragoso, \& P. Lavelle. "Are earthworms important in the decomposition of tropical litter?" 1995 pp. 103-112. In: M. V. Reddy (ed.) Soil Organisms and Litter Decomposition in the Tropics. Oxford Publishers, New Delhi.

[27] R. P. Dales, Y. Kalaç. "Phagocytic defence by the earthworm. Eisenia foetida against certain pathogenic bacteria", Comp Biochem Physiol. 1992.101A, 3, pp. 487-490.

[28] E. B. Affar, M. Dufor, G. G. Poirier, D. Nadeau. "Isolation, purification and partial characterization of chloragocytes from the earthworm species Lumbricus terrestris". Mol Cell Biochem, 1998185: 123-133.

[29] Hideshi Kobayashi, Naoshi Ohta, Masato Umeda. "Biology of Lysenin, a Protein in the coelomic fluid of earthworm Eisenia foetida". International Rev. of Cytology. 2004, 236, pp. 45-98.

[30] Weidong Pan, Sianghui Liu, Feng Ge, Tao Zheng. "Reconfirmation of antimicrobial activity in the coelomic fluid of the earthworm Eisenia foetida Andrei by colorimetric assay". J. Biosci. 2003, 28 6, pp. 723-731.

[31] S. S. Hamed, E. Kauschke, E. L. Cooper. "Cytochemical properties of earthworm coelomocytes enriched by Percoll. In: A New Model for Analyzing Antimicrobial Peptides with Biomedical Applications”. Beschin A, Bilej M, Cooper EL [Eds], IOS Press, Ohmsha, 2002. pp 29-37.

[32] A. Çotuk. and P. R. Dales. "The effect of the coelomic fluid of the earthworm Eisenia foetida sav. on certain bacteria and the role of the coelomocytes in internal defense". 1984., Comparative Biochemical Physiology, 78A 2: pp. 271-275.

[33] S. Lange, F. Nubler, E. Kauschke, G. Lutsch, E. L. Cooper, and A. Herrmann. "Interaction of earthworm hemolysin with lipid membranes requires sphingolipids". The Journal of Biological Chemistry, 1997. 272, 33: pp. 20884-20892.

[34] S. Lange E. Kauschke W. Mohrıng and E. L. Cooper. "Biochemical characteristics of Eisenia pore, a pore-forming protein in the coelomic fluid of earthworms". European Journal of Biochemistry, 1999. 262: pp. 547-556.

[35] E. L. Cooper and P. Roch. "Earthworm Immunity: a mode of immune competence". Pideobiologia. 2003, 47, pp. 676-688.

[36] M. A. Gopal, Gupta and G. V. Thomas. "Opportunity to Sustain Coconut Ecosystem Services through Recycling of the Palm Leaf Litter as Vermicompost: Indian Scenario" (A Technology/ Research Note). 2010. 26, 2: pp. 42-55.

[37] S. S. Hatti R. L. Londonkar, S. B. Patil, A. K. Gangawane and C. S. Patil. J. Crop Sci., 2010a 1,1 pp. 6-10.

[38] S. S. Hatti, R. L. Londonkar, S. B. Patil, A. K. Gangawane and C. S. Patil. J. Crop Sci., 2010 b 1,1 pp. 1-5.

[39] M. J. Prabhu. "The Hindu Newspaper", 28th December, In: Science and Technology Section. (Cited from Zambare et al, 2008), 2006.

[40] R. M. Atiyeh, S. Suler, C. A. Edwards, G. Bachman. "Effects of vermicomposts and composts on plant growth in horticultural container media and soil". Pedobiologia, 2000 44 , pp. 579-590.

[41] C. P. Fragoso, E. Lavelle, B. K. Blanchart, J. J. Senapati, Jimene, Martinez, T. Decaens \& J. Tondoh. "Earthworm communities of tropical agroecosystems: origin, structure and influence of management practices". In: Earthworm Management in Tropical Agroecosystem. CAB International. Wallingford, U. K. 1999. pp. 27-55. 